\title{
Formative Assessment for EFL Writing Class in Indonesia
}

\begin{abstract}
This assessment planned to explore the evaluation methods utilized by an educator in surveying understudies' composing abilities, the explanation in executing the strategies, and the understudies' reactions toward the execution of the procedures. The gathered information in this assessment included study hall perception that had been held in multiple times, meet, and composed report. Coming up next is the resolutions dependent on the information investigation. Since developmental appraisal of composing ability is the principle focal point of this assessment, the educator executed five composing execution undertakings proposed by Brown (2010) specifically dicto-comp, picture-signaled task, short answer task, directed inquiry and answer, and section development task. From the showing interaction done by the instructor, the evaluation errands were executed for developmental purposes, that is, to screen understudies' advancement in grasping the exercise that is about account text. The educator carried out some evaluation assignments in a casual manner to screen understudies' continuous advancement without recording the consequence of the presentation, while different errands were executed in a proper manner to record understudies' advancement and to give them an assessment of their advancement and accomplishment.
\end{abstract}

Keywords: English writing, Formative assessment, EFL students

\section{Introduction}

In instructive setting, evaluation and showing measure are indistinguishable. As recommended by Jabbarifar, evaluation centers around different parts of educating and picking up, including particular course books and educational materials, understudy accomplishment, and entire program guidance. A few specialists think about evaluation as a fundamental part of instructing and learning. Pellegrino, for example, recommend that evaluation is needed to screen understudies' demeanor and gather data to reach an objective determination about understudies' information. Numerous researchers support the idea that appraisal is helpful for educators to change the showing strategies and methods as long as it is taken care of reasonably. Numerous educators likewise accept that appraisal is an imperative instrument in putting forth understudies move their attempt in picking up, making understudies sure about their last evaluation and handiness of input in upgrading understudies' presentation.

Regardless of the exceptionally valuable parts of appraisal, it can't be disregarded that educators here and there face troubles in evaluating understudies' composing ability. Since language abilities incorporate four perspectives (tuning in, talking, perusing, and composing) and this load of abilities coordinated to each other, educators need to invest additional energy in planning and 
controlling the appraisal methods. As expressed by Brown (2010) that "the mix of abilities is of vital significance in language learning".

Moreover, if understudies are not engaged with the appraisal interaction, it implies that the evaluation isn't carried out to its full adequacy. Subsequently, O' Farrell (2004) recommends that in making appraisal plans, educators need to focus on the noticeable space of understudies' exercise, make particular learning results, and evaluate suitably. On the off chance that the appraisal isn't planned as expected, it might uncover practically zero advance and debilitate understudies. Pellegrino et al. (2001) even adds that successful educators need to utilize fluctuated types of evaluation just as to give input on understudies' advancement. Besides, educators need to plan an appraisal plan adequately and productively to get a bona fide consequence of understudies' advancement recorded as a hard copy expertise and to give criticism in improving understudies' exhibition. Various specialists had been directed investigations concerning Formative evaluation or composing expertise. Some of them led concentrates in the space of homeroom evaluation, and impression of appraisal. Those past assessments are as per the following. Jabbarifar (2009) led an assessment which was expected to take a gander at the significance of homeroom appraisal and assessment benefits just as to introduce some valuable appraisal and assessment methods which can help language instructors to make dynamic study hall circumstance for assessment. Ramadani (2014) additionally directed an assessment to research the appraisal methods utilized by educators in surveying understudies' talking expertise. Another assessment came from Ndalichako (2015) which explored discernments that instructors have in the appraisal that are probably going to impact their evaluation rehearses. Mussawy (2009) likewise endeavored to investigate pre-administration educators' impression of study hall appraisal and the employees' view of homeroom evaluation just as their assumptions for understudies' learning.

Albeit a few assessments concerning the evaluation interaction have been led, it is still absence of studies concerning the appraisal methods about developmental appraisal recorded as a hard copy expertise. Consequently, this investigation expects to fill the hole by breaking down developmental evaluation recorded as a hard copy abilities. Moreover, this assessment intends to uncover the instructor's justification carrying out the procedures just as the understudies' reactions of the execution of the strategies. By directing this assessment, it will be uncovered 
whether the educator utilized fluctuated types of evaluation and whether the appraisal is executed to its full viability.

\section{Method}

This assessment was directed by a subjective exploration plan as this investigation endeavored to depict the appraisal procedures utilized by an instructor in surveying understudies' language abilities. Subjective exploration, as expressed by Creswell (2014), alludes to "a methodology for investigating and understanding the significance people or gatherings attribute to a social or human issue". As per Denzin and Lincoln, subjective assessment is fitting to utilize on the grounds that it endeavors to consider things in their regular settings, to figure out, or decipher, wonders as far as the implications individuals bring to them (in Creswell, 2013).

\section{Exploration Site and Participants}

This assessment was led in a middle school. There are two reasons why the school was picked as the setting for this assessment. To start with, the educator in that school was able to do the exploration. Second, the school was picked for its accessibility since the authority of the school permitted the analyst to direct the assessment around then. In the meantime, the members engaged with this assessment were an English educator and a class of 10th grade of middle school understudies.

The methods utilized are study hall perception, meet, and composed archive. This is in accordance with Klenke (2016) who accepts that "different instruments are regularly utilized to gather information for contextual analyses, including interviews, utilization of recorded information or archives, or member perception". The detail cycle of information assortment will be depicted underneath.

\section{Study hall Observation}

The principal instrument utilized to respond to the exploration question was study hall perception. As per Cowie, "Perception is the cognizant seeing and point by point appraisal of members' conduct in a naturalistic setting". Perception regularly appears as two ideal sorts including member and non-member. The sort of perception led in this investigation was nonmember perception, where the scientist saw without partaking and isolated from the wonder. To assist the scientist with noticing all the homeroom exercises and to finish the data, video recording was utilized in this assessment. It's anything but a rich source since it caught every one of the things occurred or arose during the study hall perception. The information of study hall 
perception that was recorded on the video recorder was changed over to video record. The analyst led the perception in a class of 10th grade. There were three observational visits for 100 minutes (2 learning hours) in each visit. The observational visits were planned to find what sort of evaluation strategies utilized by the educator in surveying understudies' composing expertise. It was seen through educator understudies' connection and the entire study hall movement.

\section{Conclusion}

In view of the perception, the undertakings carried out by the instructor were coordinated with one another to accomplish the primary target of the exercise, that is, understudies can compose an account story by their own words exclusively. Notwithstanding, the consequences of the assessment depicted a few instances of appraisal task that elaborate composing execution. Consequently, the instructor carried out dicto-comp in the main gathering to acquaint understudies for certain story messages. Short answer task alongside directed inquiry and answer were executed to check understudies' understanding of the writings and whether they assimilated the data well. Then, at that point, the image prompted task was executed in the subsequent gathering to acquire the understudies' revenue in learning the conventional construction of account text by giving bits of funnies. By directing the image signaled task, the educator had the option to give them a training on the most proficient method to dissect conventional designs and language highlights of the account text. Finally, section development task was carried out to check understudies' individual ability recorded as a hard copy an account story.

\section{References}

Albana, H. H., Marzuki, A. G., Alek, A., \& Hidayat, D. N. (2020). Cohesive Devices in Student's Writing (A Discourse Analysis on Argumentative Text). Jurnal Pendidikan Humaniora, 8(1), 6-11.

Alek, A., Marzuki, A. G., Farkhan, M., \& Deni, R. (2020). Self-Assessment in Exploring EFL Young learners' Speaking Skill. Al-Ta lim Journal, 27(2), 208-214.

Alek, A., Marzuki, A. G., Farkhan, M., Surahman, D., Daryanto, D., \& Febrianto, S. (2020). Computer Based Testing in Senior High School on National Assessment. Indonesian Journal of Learning Education and Counseling, 2(2), 204-210. Angeles: University of California.

Belanger, J. (2004). 'When Will We Ever Learn?': The Case for Formative Assessment Supporting Writing Development. English in Australia, (141), 41.

Brown, H. D. (2010). Language Assessment: Principles and Classroom Practices (Second Edi). New York: Pearson Education Inc. 
Burner, T. (2016). Formative assessment of writing in English as a foreign language. Scandinavian Journal of Educational Research, 60(6), 626-648.

Burner, T. (2016). Formative assessment of writing in English: A school-based study of perceptions, practices and transformations.

Chappuis, S., Stiggins, R., Arter, J., \& Chappuis, J. (2004). Assessment for Learning. Portland: Assessment Training Institute.

Fatimah, A. S., Santiana, S., \& Saputra, Y. (2019). Digital Comic: An Innovation of Using Toondoo As Media Technology for Teaching English Short Story. English Review: Journal of English Education, 7(2), 101-108.

Frey, N., \& Fisher, D. (2013). A formative assessment system for writing improvement. English Journal, 66-71.

Furtak, E. M., \& Ruiz-Primo, M. A. (2008). Making students' thinking explicit in writing and discussion: An analysis of formative assessment prompts. Science Education, 92(5), 799824.

Garrison, C., Ehringhaus, M. (2013). Formative and Summative Assessments in the Classroom. Association for Middle Level Education. Retrieved from https://www.amle.org/BrowsebyTopic/WhatsNew/WNDet/TabId/270/

ArtMID/888/ArticleID/286/Formative-and-Summative-Assessmentsin-theClassroom.aspx

Graham, S., Harris, K., \& Hebert, M. A. (2011). Informing writing: The benefits of formative assessment. A Carnegie Corporation Time to Act report. LI RESEARCH ARCHIVES ONLINE.

Graham, S., Hebert, M., \& Harris, K. R. (2015). Formative assessment and writing: A metaanalysis. The Elementary School Journal, 115(4), 523-547.

Horstmanshof, L., \& Brownie, S. (2013). A scaffolded approach to discussion board use for formative assessment of academic writing skills. Assessment \& Evaluation in Higher Education, 38(1), 61-73.

Keen, J. (2005). Assessment for writing development: Trainee English teachers' understanding of formative assessment. Teacher Development, 9(2), 237-253.

Klute, Mary. (2017). Formative assessment and elementary school student academic achievement: A review of the evidence. U.S. Department of EducationR EL 2017-259

Korkmaz, S., \& Öz, H. (2021). Using Kahoot to Improve Reading Comprehension of English as a Foreign Language Learners. International Online Journal of Education and Teaching, 8(2), 1138-1150.

Kuliahana, A., \& Marzuki, A. G. (2020). Repetition Technique in an EFL Speaking Class in Islamic Higher Education in Indonesia. Academic Journal Perspective: Education, Language, and Literature, 8(1), 20-28.

Landauer, T. K., Lochbaum, K. E., \& Dooley, S. (2009). A new formative assessment technology for reading and writing. Theory into Practice, 48(1), 44-52. 
Lee, I. (2011). Formative assessment in EFL writing: An exploratory case study. Changing English, 18(1), 99-111.

Marzuki, A. G. (2019). The Implementation of SQ3R Method to Develop Learners' Reading Skill on Islamic Texts in EFL Class in Indonesia. Register Journal, 12(1), 49-61.

Marzuki, A. G. (2019). Utilizing Recorded English Dialogues in Teaching English Word Stress to Islamic Higher Education Learners in Indonesia. Jurnal Pendidikan Islam, 5(1), 53-64.

Marzuki, A. G., Alim, N., \& Wekke, I. S. (2018). Improving the reading comprehension through cognitive reading strategies in language class of coastal area in indonesia. In IOP Conference Series: Earth and Environmental Science, 156(1), 012050). IOP Publishing.

Marzuki, A.G. (2016). Utilizing cooperative learning in islamic college learners' classroom. IJEE (Indonesian Journal of English Education), 3(2), 123-139.

Marzuki, A.G. (2017). Developing speaking skill through oral report in an efl class in indonesia. Al-Ta lim Journal, 24(3), 243-254.

Marzuki, A.G. (2017). Utilizing pictures in increasing learners' vocabulary mastery in an efl class in palu city indonesia. Musawa: Journal for Gender Studies, 9(2), 191-233.

Mohamadi, Z. (2018). Comparative effect of online summative and formative assessment on EFL student writing ability. Studies in Educational Evaluation, 59, 29-40.

Mussawy, S., A., J. (2009). Assessment Practices: Student' s and Teachers 'Perceptions of Classroom Assessment University of Massachusetts School of Education, 1-115.

Reising, B. (1997). The formative assessment of writing. The Clearing House, 71(2), 71-72.

Saeed Alharbi, A., \& Meccawy, Z. (2020). Introducing Socrative as a Tool for Formative Assessment in Saudi EFL Classrooms. Arab World English Journal (AWEJ) Volume, 11.

Santiana, S., \& Fatimah, A. S. (2017). Prezi, Cloud-Based Presentation, for Teaching: How is it Interesting?. EduLite: Journal of English Education, Literature and Culture, 2(2), 445456.

Wragg, E. C. (2003). Assessment and Children's Learning in the Secondary School. London: RoutledgeFalmer.Ndalichako, J. L. (2015). Secondary School Teachers' Perceptions of Assessment. International Journal of Information and Education Technology, 5(5), 326330. https://doi.org/10.7763/IJIET.2015.V5.524 
